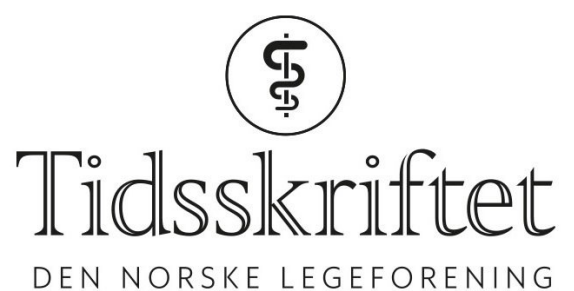

DEN NORSKE LEGEFORENING

\title{
T.T. Serkland og medarbeidere svarer
}

KOMMENTAR

\section{TROND TRAETTEBERG SERKLAND}

E-post: trond.tretteberg.serkland@helse-bergen.no

Trond Trætteberg Serkland er konstituert overlege ved Seksjon for klinisk farmakologi, Avdeling for medisinsk biokjemi og farmakologi, Haukeland universitetssjukehus.

\section{THOMAS PAHR}

INGRID ANNA TEIGEN

\section{JON ANDSNES BERG}

Ingen av forfatterne har oppgitt interessekonflikter.

Vi takker Jørgen Bramness og Vigdis Vindenes for en velskrevet kommentar til vårt innlegg i Språkspalten, og deres tilslutning til at «medisinsk cannabis» er et problematisk uttrykk.

Kommentaren peker treffende på at analogien mellom opioider og cannabinoider ikke kan anvendes fullt ut farmakologisk, og at det er farmakologisk upresist å si at cannabinoider uten videre virker på cannabinoidreseptorer, siden substansene ikke defineres ut fra dette.

Hensikten med analogien i Språkspalten er imidlertid å gi en didaktisk framstilling av hvor misvisende uttrykket «medisinsk cannabis» kan være. Vi vil fastholde at det kan sammenstilles med å anvende «medisinsk opium», og dermed er utdatert.

Det at definisjonen av cannabinoider i Pertwees oppslagsverk ikke omfatter syntetiske cannabinoider, løses ved å nettopp sette ordet «syntetisk» foran cannabinoider, slik vi beskriver i Språkspalten.

Det at «opioid» ikke brukes om opioidreseptorantagonister, som nalokson, er vi ikke nødvendigvis enige i. I Westins innlegg i Språkspalten, som det henvises til i kommentaren, er nalokson inkludert.

Om det skulle etableres som en sannhet at CBD ikke er en cannabinoidreseptorantagonist, vil den ikke falle inn under vår bruk av cannabinoidbegrepet i legemiddelsammenheng. Det hadde selvsagt vært å foretrekke om vi kunne finne en nomenklatur som også rommet denne substansen, men den må i tilfelle bli stående som et av unntakene som bekrefter regelen. 